\title{
About Oral Hygiene in Children - an exploratory study
}

\section{Acerca da Higiene Oral em Crianças - Um estudo exploratório}

\author{
Katia Paramés Ferreira e Lídia Correia Lopes \\ CBIOS - GQESSE-Gabinete da Qualidade e Estudos Sociais em Saúde da ERISA, \\ Escola Superior de Ciências da Saúde - Rua Telhal aos Olivais, 8 - 8A 1900-693 Lisboa \\ E-mail: katia.parames@gmail,com
}

\begin{abstract}
We developed an applied research project on oral hygiene in children between the ages of 4 and 5 years old during the 2nd Supplementary Training Course in Nursing at ER ISA. This research is char acterized as a descriptive, transversal and quantitative exploratory study, and was applied to 25 children attending the last year of early childhood education during the 2008/2009 academic year in a private school in Oeiras municipality. This study al lowed us to identify these children's oral hygiene habits as well as the training and support given by their parents and the School in this area as well. We concluded that there were several gaps in the hab its and student's awareness regarding oral hygiene. We also determined that these gaps could not be solved simply by training programs exclusively geared to children, therefore making it also necessary to involve the school community including the student's parents. Thus, in order to accomplish this mission, we planned and implemented a series of activities that were addressed to the parents, the children and, indirectly, to the school.
\end{abstract}

Keywords: Oral Hygiene, Children, applied Research, School's Health.

\begin{abstract}
Resumo
Durante o $2^{\circ}$ Curso de Complemento de Formação em Enfermagem na ERISA, foi desenvolvido um projecto de investigação-acção sobre higiene oral de crianças de 4 e 5 anos de idade. A investigação foi real izada através de um estudo exploratório - descritivo, transversal e quantitativo aplicado a 25 crianças que frequentaram oúltimo ano de educação infantil, no ano lectivo 2008/2009 de um colégio privado no Concelho de Oeiras. Este estudo permitiu identificar quais os hábitos de higiene oral destas crianças e a formação e apoio dado pelos pais e pela escola nesta área. Concluíl-se que havia lacunas nos hábitos e conhecimentos dos alunos no que diz respeito à higiene oral. Determinou-se que estas lacunas não podiam ser resolvidas com acções de formação dirigidas exchusivamente às crianças, mas que era necessário envolver, na sua dinâmica, também toda a comunidade escolar e os pais dos alunos. Assim, para que esta missão fosse concretizada, foramplaneadase implementadas uma série de actividades dirigidas aos pais, aos alunos e indirectamente à escola.
\end{abstract}

Palavras-chave: Higiene Oral, Infantil, Investigação-acção, Saúde Escolar. 


\section{Introduction}

Oral disenses affects a wide portion of the Portuguese population, thus being a serious public health problem. The negative impact of these diseases and the low-income of most families makes us believe that an adequate, continuous and effective prevention is the right path to pursue in order to reduce related problems. This prevention results in daily habits (oral hygiene and healthy foods) that lead to good oral health. This prevention is particularly important during childhood since it is during this period that future habits are acquired and for that reason it is pertinent to act on this population when the intention is to improve oral health in the gerieral population. Thus, we've developed a professional intervention project in an academic context ( $2^{\text {od }}$ ERISA's Supplementary Nursing Training Course). Its main purpose was to improve oral hygiene habits in children between the ages of 4 and 5 at a private school in Oeiras - the Instituto Español de Lisboa Giner de los Rfos, during 2008/2009 academic year. The general objective was achieved through three specific objectives -to carry out a research study on the oral hygiene habits in children; to promote training sessions on oral hygiene habits for children; to include /hold parents responsible in the project and provide sufficient information so that this program could "continue" at home.

This project had 5 stages - initial assessment (research the theme at a national scope), diagnose the main problems related to oral hygiene (in a specific context through a research study), plan the training sessions (based on the results of the study), implement the activities and finally, the conclusion assessment of the entire Project. [D]

The National Health Plan (PNS) $2004 / 2010$ is a management instrument that sustains the National Health Care Service. Its aim is to guarantee the attainment of "Health Gains" between 2004 and 2010 being therefore supported by activitics (distributed by 40 National Programs) that contribute to these "gains". These activities are implemented in several locations, with the school being of the utmost importance for the PNS because it plays a key role in the lifestyles acquisition process. It is within this scope that the National School Health Program (PNSE) fits into it. Therefore, there is a partnership between the Ministries of Health and Education so that both assumed to invest to fulfill this Program. ${ }^{[4,5]}$ The implementation of School Health is local Health Centers responsibility which shall provide the necessary professionals (School Health teams, including community health nurses) to go to the school and to carry out the necessary programs. These professionals use Education for Health $(\mathrm{EH})$ as the

\section{Introduçüo}

As doenças orais atingem grande parte da populaçăo portuguesa, constituindo um grave problema de saúde pública. Onegativo impacto destas doenças e o débil poder económico da generalidade das familias, faz acreditar que uma prevençāo adequada, continua e eficaz, é cominhoa seguir para travaros niveis desteproblema. Esta prevenç̧o traduz-se em híbitos diários (higiene oral e alimentaçĩo saudável) que levarn a uma bog saúde oral, e. Esta prevenção é especialmente importante na infância, já qué nesta idade que se adquirem os hábitos para o futuro, e por isso parece pertinente a actuaçăo sobre csta populaçăo quando se pretende melhorar a saúde oral da populaçâo em geral, $^{[1,2]}$

Assim, realizou-se um projecto de intervenção profissional em contexto académico ( $2^{\circ}$ Curso de Complemento de Formação em Enfermagem da ERISA) com o objectivo geral de melhorar os hábitos de higiene oral em crianças de 4 e 5 anos de idade, que frequentarn um colégio da área de Oeiras - Instituto Español de Lisboa Giner de los Rios -, no ano lectivo 2008/2009. O objectivo geral foi concretizado através de três objectivos cspecificos: realizaçĩo de um estudo de investigação sobre os hábitos de higiene oral das crianças; realização de actividades de formação sobre hábitos de higiene oral para as crianças; inclusåo/responsabilização dos pais neste projecto, fornecendo informaçāo, para que este programa seja "continuado" em casa.

Este Projecto passou por 5 etapas - avaliação inicial (pesquisa sobre esta temática em âmbito nacional), diagnóstico dos principais problemas relacionados com a higiene oral (em contexto específico através do estudo de investigação), planeamento de actividades formativas (baseadas nos resultados do estudo), implementaçāo de actividadese,por fim, avaliação final de todo o Projecto ${ }^{\text {'t' }}$. O Plano Nacional de Saúde (PNS) 2004/2010 é um instrumento de geståo para sustentar o Sistema Nacional de Saíde. Tem o objectivo de assegurar a obtençüo de "Ganhos em Saúde", de 2004 a 2010, e portanto é formado por actividades (distribuidas por 40 Programas Nacionais) que contribuem para estes "ganhos". Estas actividades implementam-se em diversos locais, sendo a Escola um dos mais importantes parn o PNS, porque esta desempenha um papel primordial no processo do aquisiçî́o de estilos de vida. É neste âmbito que se enquadra o Programa Nacional de Saúde Escolar (PNSE). Assim, existe uma parceria entre os Ministérios de Saúde e da Educação, onde ambos assumiram um investimento para a concretização deste Programa, ${ }^{\text {k9 }}$

A implementaçâo da Saúde Escolar é da competência dos Centros de Saúde, que devem disponibilizar profissionais (equipas nucleares de Saúde Escolar, das que fazem parte enfermeiros de saúde comunitária) que vāo às escolas executar os Programas necessários. Estes profissionaís utilizam a Educação para a Saúde (ES) como principal instrumento de acção. $\mathrm{Na}$ ES nes crianças em idade escolar, devemos explicar o porquê de se fazerem as coisas de uma maneira e näo de outra, de forma que 
main action instrument. In EH directed to school children we should explain why we do things that way, so that they might understand and interiorize concepts and apply them in the right situations. ${ }^{[3,9,6]}$

In School Health, the nurse is part of a multiprofessional team wher health professionals and the educational community meet. This team should work with the student's family since this is the child's "first school", and at bome, which is where many of our life habits are learned. However, we should not forget that children often don't accept the parent's guidance, favoring external guidance from outside of the family. In this sense, our intervention is essential when it acts directly on the child and when is used with other participants as intermediaries - it is an intervention from several angles. At this age, friendly directives, coming from individuals with the same age are also very influential. This may be advantageous for us when EH is implemented in a wide number of children. ${ }^{[0,4, T, a, 9]}$

The oral health promotion in children is one of the PNS intended goals. It is within this scope that the National Program for the Promotion of Oral Health (PNPSO) should be included in some of the other 40 National Programs, including the PNSE. ${ }^{[<\%]}$

It was based on the PNPSO that we determined which indicators to use in the present study, in order to decide if oral hygiene in this children's population is effective or not. Some of the PNPSO's main issues shall be highlighted:

- Caries and periodontal disease are the most frequent oral cavity diseases., If adequately forewarned and early treated, both decrease its level vulnerability and may even be eliminated. This prevention leads to an effective oral hygiene and "orally" healthy foods.

We shouldn't forget the importance of a reinforced hygiene when the permanent teeth begin to erupt since these are more vulnerable to caries. Thus, the PNPSO gives us all of the age related directives on how to carry out oral hygiene.

Regarding food, it is known that children who consume more food with higher sugar content, especially outside meals, have an increased carie's susceptibility. The school plays a fundamental role regarding promotion of good eating habits. The food offer should be healthy foods, avoiding sugar rich products. Parents also play a fundamental role in this area. There should never be contradictions between the nutritional teaching and what is given to children to eat.

We may assume that oral health totally depends from the application of oral hygiene habits and food supporting those habits. In this sense, we intend to develop activities within this project that will always be based on these two aspects - oral hygiene and "orally healthy" foods. ${ }^{\text {'M }}$ entendam os conceitos e os interiorizem, para a partir dal os aplicarem nas situações indicadas. ${ }^{\text {p: }}$ क.

$\mathrm{Na}$ Saúde Escolar, o enfermeiro trabaha inserido numa equipa multiprofissional constituida relos profissionais de saúde e pela comunidade educativa. Esta equipa deve trabalhar em conjunto com a familia do aiuno, já que esta é a "primeira escola" da criança e, é em cesa, onde se aprendem muitos dos hábitos para a vida. Mas nåo devemos esquecer que, frequentemente, a criança não aceita as orientaçoes dadas pelos pais, mas sim as de elementos externos à familia. Neste sentido, a nossa actuaçĩo é essencial, tanto quando essa actuaçäo ê directa sobre a criança, como quando usamos outros intervenientes como intermediários - é uma actuaçäo em vários angulos. Nesta idade, também sạ̃o de grande influência as directrizes dadas pelos amigos da mesma idade, podendo ser esta característica um trunfo a nosso favor quando se decide implementar a ES num grande número de crianças. ${ }^{11.5, ?, 89}$

Uma das metas que se pretende cumprir com o PNS é o incremento da saúde oral nas crianças. Ê nesto âmbito, que se enquadra o Programa Nacional de Promoçäo de Saúde Oral (PNPSO) que deve ser incluido em alguns dos outros 40 Programas Nacionais, entre eles no PNSE. ${ }^{[2,4,91}$ É com base no PNPSO que se determinaram os indicadores utilizados no estudo deste Projecto, para identificar se a higiene oral, das criançs incluidas nesta amostragem, ê ou não eficaz. Assim, torna-se essencial ressaltar alguns pontos principais do PNPSO:

- A cárie e a doença periodontal sio as doenças da cavidade oral mais frequentes. Ambas, se adequadamente preverilidas e precocemente tratadas, diminuem o seu grau de vulnerabilidade ou podem mesmo serem suprimidas. Esta prevençĩo traduz-se, numa higiene oral eficaz e numa alimentaçăo "oralmente" saudável.

Não devemos esquecer a importância de uma higiene reforçada quando os dentes permabentes começam a erupcionar, já que estes dentes são mais vulneráveis à cárie. Assim, o PNPSO, dá-nos todas as directrizes sobre a forma como deve ser feita a higiene oral nessas idades.

Em relação d̀ alimentação, sabe-se que as crianças que consomem mais alimentos ricos em açúcar, especialmente fora das refeições, tên susceptibilidade aumentada à cárie dentária. A Escola tem um papel fundemental na preconização de bons hábitos alimentares, pelo que a oferta de alimentos deve estar direccionada a alimentos saudáveis, fugindo de produtos ricos em açícares. Os pais tamben têm um papel fundamental nesta área, nunca devendo haver contradições entre os ensinamentos do que se deve comer e o que se dá a comer às crianças.

Pode, assim, dizer-se que a existência de saúde oral passe, quase completamente, pela aplicaçio de hábitos de higiene oral e por uma alimentaçäo beneficiária para esta. Neste sentido, as actividades que se pretendem desenvolver com este Projecto terďo sempre como báse estes dois aspectos: higiene oral $\mathrm{e}$ alimentação "oralmente saudável".

Foi definido um objectivo geral - Determinar quais os 
We carried out a study with one general objective, aiming to Determine oral hygiene habits in children between the ages of 4 and 5 - and four other specific objectives, aiming to Identify the oral hygiene habits; to identify the eating habits; to identify the participation and help given by parents for good oral hygiene; and to identify the participation and help given by the school for good oral hygiene.

The leading question - Which are the oral hygiene habits for children between the ages of 4 and 5 ? was determined through the following research questions: Q1. What are the children's oral hygiene habits?; Q2. What are the children's food eating habits?; Q3. Do parents participate in training children to acquire oral hygiene habits?; Q4. Do parents help children in carrying out oral hygiene?;Q5. Does the school participates in training children to acquire oral hygiene habits?; Q6. Does the school participates helping children to acquire an effective oral hygiene?

\section{Material and Methods ${ }^{|12,11,12,13|}$}

This was a descriptive (level $\mathrm{n}$ ), transversal and quantitative exploratory study.

The study population inluded children attending the last year of early childhood education, during the $2008 / 2009$ academic year (between the ages of 4 and 5 ) at a school in the Oeiras Municipality. The sample included all children who volunteered, following their parents' consent, to participate in the interview. In order to proceed with the data gathering, formal authorization were previously requested to the School Board and then to the parents. Both requests included an informed written consent where the framework, objectives and the possibility to stop participating in this study at any moment as well as the anonymity of the data were fully described. This was a convenience sample as opposed to a probability sample, since interviewed children were those available by September 29th and October 1st (2008) (the time needed for data gathering determined the size of the sample). The sample included 25 children, 4 of which $(16 \%)$ were 4 years old and $21(84 \%)$ were 5 years old. Of these, $11(44 \%)$ were male and 14 $(56 \%)$ were female.

As for the data gathering instrument, we selected a form with 16 open and closed questions, 5 of which were subdivided, applied through a structured and uniform informal interview with the children, since they still do not know how to read and write at this age. This form was previously submitted to a pretest with 3 children between the ages of 4 and 5 . The aim of this form was to respond to the 5 research questions that had been previously formulated (Appendix $n^{\circ}$. 1). For data analysis, we determined the following hábitos de higiene oral des crianças entre os 4 e os 5 anos, e quatro objectivos especificos consistindo em Identificar quais são os hábitos de higiene oral; Identificar quais são os hábitos alimentares; Identificar qual é a participação e a ajuda proporcionadas pelos pais para a exístência de uma boa higiene oral; Identificar qual é a participação e a ajuda proporcionadas pela escola para a existencia de uma boa higiene oral.

A pergunta de părtida do estudo - Quais são os hábitos de hígiene oral dás crianças entre os 4 e os 5 anos de idade? -, determinou-se através das seguintes questões de investigação: Q1. Quais são os hábitos de higiene oral das crianças?; Q2. Quais são os hábitos alimentares das crianças?; Q3. Os pais participam na formação dada ds crianças para a aquisição de hábitos de higiene oral?; Q4. Os pais ajudam as crianças no desempenho da sua higiene oral?; Q5. A escola participa na formaçāo dada às crianças para a aquisição de hábitos de higiene oral?; Q6. A escola participa na ajuda dada as crianças para a aquisição de uma eficaz higiene oral?

\section{Material e Métodos ${ }^{\text {|a, } 14,14, \text { Un }}$}

Tratou-se đe um estudo exploratório, descritivo (nivel I), transversal e quantitativo.

A população do estudo foi constituida pelas crianças que frequentaram o último ano de educuçăo infantil, no ano lectivo de 2008/2009 (entre os 4 e os 5 anos de idade) de uma escola do Concelho de Oeiras. A amostra fol constituida por todas as crianças que, tendo a autorização dos pais, se disponibilizaram voluntariamente para responder à entrevista que foi efectuada. Para proceder a esta colheita de dados solicitou-se, primeiro, autorização ao Director da Escola e, posteriormente, aos pais. Ambas as solicitaçōes, foram feitas por escrito, através de um consentimento informado onde se explicou o enquadramento, os objectivos, a possibilidade de desistir da participação do estudo em qualquer momento e o anonimato dos dados. Foi uma amostra de conveniencia e não probabilistica, já que foram entrevistadas as crianças que estiveram mais disponiveis em cada momento, desde o dia 29 de Setembro até ao dia 1 de Outubro de 2008 (o espaço de tempo para a colheita de dados determinou o tamanho desta amostra). A amostra foi constituida por 25 crienças, das quais 4 (16\%) tinham 4 anos e $21(84 \%)$ tinham 5 anos de idade, sendo que 11 (44\%) eram do sexo masculino e $14(56 \%)$ do sexo feminino.

Como instrumento de colheita de dados, seleccionou-se um formulário (constituído por 16 perguntas fechedas e abertas, das quais 5 subdivididas) que foi aplicado através duma entrevista informal, estruturada e uniformizada, com as crianças, já que nesta idade elas não sabem ler nem escrever. Este formulário foi submetido primeiramente a um pré-feste com 3 crianças de 4 e' 5 anos de idade. $O$ objectivo deste formulário foi responder às 5 questð̃es de investigação formuladas anteriormente (Apêndice $\mathrm{n}^{0} 1$ ). Para a análise de dados, foram determinadas as seguintes variáveis de estudo: Variável dependente: Hábitos de 
variables - Dependent variable, oral hygiene habits used by the children (Indicators: tooth brushing frequency; the time when they brush their teeth; use or non-use of floss; toothbrush care; frequency with which high sugar foods are eaten, the time that high sugar foods are eaten.). Independent variables, sample characteristics (age and gender); Education and help given by parents in relation to oral hygiene (help brushing the teeth if the child does not have enough skill; supervise the child as they brush their teeth, and if the child does it alone, they should check to see if the brushing was adequate; training given to children on oral hygiene and eating habits); Training and help given by the school in relation to oral hygiene (training given to children on oral hygiene and eating habits; help offered to children by the School to obtain good oral hygiene).

For data treatment, considering the sample size, no inferential statistics was performed. Instead we applied descriptive statistics. As all the variables were discrete (nominal and ordinal), we used a frequency table for its description (Appendix no. 2).

\section{Results and Dlscussion}

In relation to how many times they brush their teeth per day, we saw that 17 children (68\%) brushed their teeth 2 or more times per day, but there were still 8 (32\%) that did it less than twice a day, in clear contrast with the PNPSO's indication.

Regarding the time period for tooth brushing 16 children (64\%) always brushed their teeth before going to bed, but still a considerable number $-9(36 \%)$ never did-it. 8 children (33.3\%) brushed their teeth after high-risk behavior (sugar intake), but 16 (66.6\%) not always. 0 . Only 1 child $(4 \%)$ brushed their teeth at school while $24(96 \%)$ did not. According to the PNPSO daily tooth brushing should be included before bed, and always after sugar food intake. The scholar schedule does not include tooth brushing, but PNPSO recommends that this practice should be included in the school curricula so that children may acquire these hygiene habits as soon as possible.

Regarding the tooth brushing 14 children (56\%) always brushed their tongue during oral hygiene, while $11(44 \%)$ didn't. 8 children ( $32 \%$ ) knew dental floss. In these, only $2(25 \%)$ used it regularly, while the other $6(75 \%)$ didn't. The remaining $68 \%{ }^{\left[{ }^{[i 7}\right.}$ didn't knew it at all, despite the fact that some have already heard about it.

We consider that the number of children who wash their tongues while brushing their teeth ${ }^{t / 9}$ is fairly high, since it is not a nomnal practice among adults. Children normally imitate adults so this behavior is quite unusual. This is a recommended practice, but higiene oral utilizados pelas crianças (Indicadores: frequência com que escovam os dentes; momento em que é feita a escovagem de dentes; utilização ou não do fio dentário; cuidados a ter com a escova de dentes; frequência com que comem alimentos açucarados; momento em que comem alimentos açucarados.). Variáveis independentes: Características da amostra (idade e género); Formaçăo e ajuda dada pelos pais em relação a higiene oral (ajuda na lavagem dos dentes, se a criança não tiver destreza suficiente; supervisão da criança durante a lavagem dos dentes, se esta o fizer sozinha, para aferir so a lavagem é feita de forma adequada; formação dada às crianças sobre os hábitos de higiene oral e alimentares); Formação e ajuda dada no meio escolar em relação à higiene oral (formação dada às crianças sobre os hábitos de higiene oral e alimentares; ajuda proporcionada pela Escola, às crianças, para a obtençũo de uma boa higiene oral).

Para o tratamento de dados, não foi utilizada a estatística inferencial devido à dimensẵ da amostra, pelo que foi apenas usada estatistica descritiva. Como todas as variáveis eram discretas (nominais e ordinais), utilizou-se un quadro de frequência para a sua descrição (Apêndice $\left.n^{\circ} 2\right)$.

\section{Resultados e Discussão}

Em relação ao número de vezes que lavam os dentes por dia, determinou-se que 17 (68\%) crianças lavavam os dentes 2 ou mais vezes, mas $8(32 \%)$ faziam-no menos de duas vezes por dia, contrariamente ao indicado pelo PNPSO.

No que concerne ao momento em que é feita a escovagem de dentes 16 crianças (64\%) lavavam sempre os dentes antes de ir dormir, mas um número ainda considerável, 9 (36\%) nem sempre o fazia . 8 crianças $(33,3 \%)$ lavavam os dentes após comportamentos de risco (ingestão de açúcar), enquanto que $16(66,6 \%)$ nem sempre o fazia. (*) . 24 crianças $(96 \%)$ não lavavam os dentes na escola. Apenas 1 o fazia (4\%).

Segundo o PNPSO uma das escovagens diárias tem de ser feita antes de dormir, e sempre que existir uma ingestão de alimentos açucarados. O facto de nenhuma das escovagens ser feita no horário escolar é uma má prática, já que a proposta do PNPSO é que esta técnica seja incluida no curriculum escolar para que as crianças possam adquirir estes hábitos de higiene.

Em relação à forma como é realizada essa escovagem dos dentes, 14 (56\%) crianças lavavam sempre a lingua no momento de realizar a higiene oral, e $11(44 \%)$ nem sempre o fazia. $8(32 \%)$ crianças sabem o que é o fio dentário e destas, só 2 (25\%) delas o utilizava com regularidade, sendo que as outras $6(75 \%)$ não o utilizavam. As restantes $68 \%$ "1เท não sabiam o que é, apesar de algumas delas já terem ouvido falar nele.

Constatamos que o número de crienças que lava a língua durante a escovagem dos dentes ${ }^{\text {Ital }}$ é bastante elevado, já que não é um hábito muito praticado pelos ađultos, sendo normal que também nĩo o seja pelas crianças que os 
nevertheless, the PNPSO does not consider it mandatory for an effective oral hygiene. Regarding the floss, the reduced number of children 8 recognizing it is probably normal at this age.

Regarding the consumption of high sugar food intake we found out that:

-22 children ( $88 \%$ ) cọnsumed two, or less, sugar food per day. $3(12 \%)$ referred more than 2 sweets per day. In relation to the time of the day when they consumed sweets $04(16.7 \%)$ consumed sweets during meals, while $20(83.3 \%)$ consumed them out of meals. Children's majority consumed sweets at home or at parties. The second indicated place to eat sweets was the school ( 5 children) with the remaining referring restaurants or the park ㅁ. We cannot thoroughly criticize the number of times children consume sweets, since the PNPSO does not rigorously define that aspect per day. But it indicates that sugar substances intake should not be excessive, also referring that it should not take place separated from meals,

Concerning parents and the school support in relation to their oral hygiene, $80 \%$ of the children (20) referred home support (help or vigilance depending on their ability) when brushing their teeth, and $20 \%{ }^{19}$ referred no support. These $80 \%$ of the children receiving parental support is considered very positive since it is one of the practices encouraged by the PNPSO. Regarding teachers support, it seems there isn't any since, as previously stated, since only one child brushes their teeth at school and this child did not received any type of help to carry out this task. Regarding the training and information on oral hygiene provided by parents and the school, 15 . children (60\%) stated that they have been taught how to brush their teeth, while 10 (40\%) didn't. In the 15 taught children, $13(86.6 \%)$ hold their parents responsible for the training, $1(6.6 \%)$ learned it from tv and $1(6.6 \%)$ didn't remember who taught him.

$72 \%{ }^{\text {III }}$ of the sumple referred to be aware about the need to wash their teeth in order to have an healthy oral condition, whereas $28 \%{ }^{[7]}$ did not know that relationship. Within those 18 aware students 10 $(55.6 \%)$ were elucidated by their parents, $1(5.6 \%)$ by the dentist, $2(11.1 \%)$ learned it on television and 5 $(27.7 \%)$ did not remember who taught them.

18 children $(72 \%)$ knew that eating too many sweets was bad for their teeth. $12(66.7 \%)$ referred their parents explaining this to them; $3(16.6 \%)$ did not remember who explained this relationship; 2 (11.1\%) knew it from the dentist and $1(5.6 \%)$ learned it from $\mathrm{a}$ teacher at his previous school. The remaining 7 students $(28 \%)$ were not informed about teeth deterioration by eating too much sweets.

Children's majority affirmed knowing how to brush their teeth, the relationship between teeth brushing imitam. Apesar de ser um hábito recomendado, o PNPSO nào o considera como obrigatório para uma higiene oral eficaz. Em relação ao facto de apenas 8 crianças saberem o que é o fio dentário, não é preocupante, já que a sua utilização não é essencial na sua idade.

Falando agora do consumo de alimentos açucarados , 22 (88\%) crianças consumiam duas, ou menos, substáncias açucaradas por dia. 3 (12\%) comiam mais de dois doces por dia. Em reláçäo ao momento em que comem os doces (*) $4(16,7 \%)$ alunos refeririram durante as refeiçōes, enquanto que os outros $20(83,3 \%)$ referiram fora das refeiçōes. A maioria das crianças consumia os doces em casa ou em festas. O segundo local referido para comer os doces foi a escola (5 crianças) e as restantes referiram fazk-lo em restaurantes ou no jardimn ${ }^{\text {[2] }}$. Relativamente ao número de vezes que as crianças consumiam doces, uma análise concreta não é possível, já que o PNPSO não define, em rigor, a quantidade de vezes que se pode comer doces por dia, indicando simplesmente que a ingestão de substâncias açucaradas nåo deve ser excessiva. Já quanto ao momento de ingestầo destas substâncies, refere que esta näo deve ser feita fora das refeições.

No que concerne à ajuda proporcionada pelos pais e pela escola em relação à sua higiene oral, $80 \%{ }^{\text {pal }}$ das crianças referiu receber apoio em casa (ajuda ou vigilância dependendo da sua destreza) no momento de lavar os dentes, e $20 \%{ }^{19}$ diznão receber qualquer tipo de apoio.

O facto de $80 \%$ das crianças receber este apoio dos pais, foi considerado como bastante positivo, já que ć uma das práticas incentivadas pelo PNPSO. Em relaçã̃o ao apoio dado pelos docentes, considerámos näo existir, visto que, como referido anteriormente, só uma criança lavava os dentes na escola e esta nâo recebia qualquer tipo de ajuda para a realização desta tarefa.

Falando agora sobre a formação e informação sobre higiene e saúde oral forneciđa pelōs país è pela escola, 15 $(60 \%)$ crianças referiram ter sido ensinadas sobre a forma de fazer a escovagem dos dentes, enquanto que $10(40 \%)$ afirmaram não ter sido ensinadas. DEas 15 crianças ensinadas, $13(86,6 \%)$ referiram ter sido os pais a dar-thes essa formaçâ, $1(6,6 \%)$ aprendeu na televisão e $1(6,6 \%)$ nåo se lembrava como aprendeu . $72 \%$ (18) da amostra referiu saber que para ter uns dentes saudáveis os deveria lavar, sendo que $28 \%{ }^{\text {M }}$ nũo sabia dessa relaçăo. Dos 18 alunos informados, : $10(55,6 \%)$ foram elucidados desta situação pelos pais, $1(5,6 \%)$ pelo dentista, $2(11,1 \%)$ aprenderam na televisão e $5(27,7 \%)$ não se lembravam como aprenderam. $18(72 \%)$ crianças sabiam que comer muitos doces faz mal aos dentes. Esta relação foi explicada a $12(66,7 \%)$ destas crianças pelos pais, 3 $(16,6 \%)$ năo se lembravam de quem thes explicou esta relação; 2 (11,1\%) sabiam através do dentista e $1(5,6 \%)$ aprendeu através da professora da antiga escola. Assim, os restantes $7(28 \%)$ alunos não sabiam que comer muitas substâncias açucaradas afecta negativamente os seus dentes.

A maioria das crianças afirmava ter conhecimentos sobre como realizar a escovagem dos dentes, saber a relação entre lavagem dos dentes e saúde oral e'também, que 
and oral health, and that eating sugar was bad for their oral health. In the three situations, the "teacher" were their parents. We therefore consider that training ind information given by the school was practically null since no children refers to it as an intervener in this context.

We have tried to respond to the initial research questions in this study:

-Q1. Which are the children's oral hygiene habits?

the study results indicate that there existed oral hygiene habits, but poorly defined in terms of space (they should brush their teeth at least once at school on a daily basis, and this did not happen) or time (even though they brushed their teeth, they did not always do it in a proper time).

Regarding the way in oral hygiene was carried out, we concluded that the majority of children washed the top part of their tongue, which was quite surprising since this is not a common practice among adults. There were many children who didn't knew floss, and even knowing it, its use was rare. Nevertheless, this was not considered as a problem since the PNPSO states that this practice should only happen when the child has gained ability for it.

\section{- Q2. What are the children's eating habits?}

Even though the majority of children referred eating less then two sweets/day, this is a difficult situation to assess since the PNPSO does not define the allowed quantity of sweets per day. Regarding location where they consume sweets, the majority of children referred home'parties, and seldom at school. This lead us to conclude that the school does not promote those habits. As for teeth brushing after sweet's intake a very.low number of children referred it.

- Q3. Do parents participate in training children to acquire oral hygiene habits? and Q5. Does the school participate in training children to acquire oral hygiene habits?

Regarding all habits learned within the scope of oral hygiene and healthy diet, we've verified that the biggest trainers/educators were parents, even considering its questionable efficiency regarding children's oral hygiene habits. In the present context the school role was considered null.

- Q4. Do parents help children carrying out oral hygiene? and Q6. Does the school participate in helping children to acquire an effective oral hygiene?

The fact that the majority of children receive support from their parents when they carry out their oral hygiene was positively regarded, since it is a practice encouraged by the PNPSO. In relation to the teachers support, we considered that there wasn't any since only one child brushed their teeth at school, and this child did not receive any type of help.

After analyzing all answers to research questions, we detected two main problems: comer muitas substâncias açucaradas prejudica a sua saúde oral. Nas trểs situaçōes, os grandes "ensinadores" foram os pais. Assim, considerámos a formaçăoo e informação dadas pela escola como nula já que nenhuma criança a referiu como interveniente neste contexto.

Com este estudo tentou responder-se is questões de investigação iniciais:

Q1. Quais são os hảbitos de higiene oral das crianças?

Os resultados do estudo indicam que existiam hábitos de higiene oral, mas insuficientemente definidos quer no espaço (uma das escovagens diárias deve ser feita na escola, e isto não acontece) quer no tempo (apesar de lavarem os dentes, nem sempre o fazem no momento oportuno).

Em relaça a d forma como era realizada a higiene oral, concluiu-se que a maioria das crianças laveva a parte de cima da sua língua, o que não deixa de surpreender, visto que não é um hảbito comum entre os adultos. Existem muitas crianças que não sabem o que é o fio dentário e os que sabem, na sua maioria não o usam. Contudo não se considera urn problema já que o PNPSO aconselha o inicio da sua utilização apenas quando a criança tiver destreza para o fazer.

Q2. Quais são os hábitos alimentares das crianças?

Apesar de a maioria das crianças referir comer menos de dois doces/dia, esta é uma situação difficil de avaliar, já que nem o próprio PNPSO determina a quantidade de doces permitida por dia. Em relaçẫo ao local onde consumiam os doces, a maioria das crianças referiu em casa/festas, e poucas vezes na escola, concluindo que a escola não é uma promotora destes hábitos. Já em relação à lavağem dos dentes após a ingestão dos doces, foi muito baixo o número de crianças que referiu realizá-la.

Q3. Os pais participam na formação dada às crianças para a aquisição de hábitos de higiene oral? e Q5. A escola participa na formação dada às crianças para a aquuisição de hábitos de higiene oral?

Em relaçín a todos os hábitos aprendidos no âmbito da higiene oral $\mathrm{e}$ de alimentaçẫo saudável, constatou-se que os maiores formadores sũo os pais, ainda que às vezes não de forma eficiente, visto que apesar das crianças terem hábitos de higiene oral, nem sempre são os mais adequados. Em relação à formação oferecida pela escola, considerou-se nula, já que nenhuma criança a referiu como formadora neste âmbito.

Q4. Os pais ajudam as crianças no desempenho da sua higiene oral? e Q6. A escola participa na ajuda dada as crianças para a aquisiçăo de uma eficaz higiene oral?

O facto de a grande maioria das crianças receber apoio dos pais, no momento de realizarem a sua higiene oral, considera-se positivo, jé que é uma prática inçentivada pelo PNPSO. Em relação ao apoio dado pelos docentes, considera-se não existir, visto que, só uma criança lavava os dentes na escola, nåo recebendo qualquer ajuda.

Após análise das respostas a todas as questōes de investigação, determinaram-se dois problemas:

- A falta de apoio dado pela escola para a promoção de hábitos que promovam a saúde oral.

- A existência de apoio parental pouco eficaz, visto que os 
- The lack of support given by the school to promote oral health habits.

- The reduced efficacy in the parental support since many of the hygiene habits are, sometimes, not correct.

Thus, this project's proposal was to apply training to teachers (sensibilize them about school's importance in acquiring oral hygiene habits, and subsequent training on effective oral hygiene routines) and parents (on children's oral hygiene training).

In order to respond to the identified needs, and keeping in mind the reduced time to implement activities, we've delineated two action strategies.

The first strategy implied creating training activities for the children with the aim of sensibilizing and training them on oral hygiene habits. However, the overall aim was to sensibilize and to train the school, showing them the modus operandi of this awareness/training process for the students so that it becomes a normal practice when implemented by the school. ${ }^{\mathrm{F}, \mathrm{g}}$

The second strategy aimed parents as the preferential target (family context) providing them with complementary educational information related with oral health. ${ }^{\text {2, }}$.

The above mentioned strategies corroborate what is foreseen by the PNPSO regarding oral health promotion within the family context and at school.

Oral health promotion was carried out in two training sessions in which a character was created and interpreted by the trainer, aiming to spread the message with an easy and attractive manner, Sessions involved all teachers and the school's nurse, as part of the school's community...These sessions involved 75 children, several didactic resources and intervention methodologies ${ }^{\mid 2,1,4,2)}$. The $I^{*}$ Training session: The relationship between oral hygiene, oral bealth and healthy foods generally aimed to show the benefits of an effective oral hygiene. Four specific objectives were delineated (to define oral health, oral hygiene, "oraily healthy" foods, and to relate the three concepts) so that this session was divided into four parts - an introduction to create a comfortable environment (several children were not confident enough about the activity) and to define some basic concepts about oral health, a second development part, to touch the children on the importance of bealthy foods and a good oral hygiene in order to obtain an effective oral bealth. And a conclusion (third part) where, by a song some of the most relevant aspects of the sessions where summarized. The las $\left(4^{\mathrm{t}}\right)$ part was the evaluation stage where we concluded that the session's objectives were fully achieved,

The $2^{\text {at }}$ Training session: The technique of brushing teeth and using dental floss, generally aimed to hábitos de higiene executados pelas crianças nem sempre eram os correctos.

Assim, foi proposta do projecto, a aplicação de formeçäo a professores (sensibilizando-os para a importância da escola na aquisição de hábitos de higiene oral, e posterior formaçã̀o sobre bábitos de higiene oral eficazes) e a pais (formação sobre higiene oral nos seus filhos).

De forma a dar resposta is necessidades detectadas através do estudó e tendo em conta a escassez de tempo para a impleméntação de actividades, delinearam-se duas estratégias de aç̧äo.

A primeira estratégia foi realizar actividades de formaçăo dirigidas às crianças com o objectivo de sensibilizí-las e formá-las em hábitos de higiene oral, mas, sobretudo, com o grande objectivo de sensibilizar e formar a escola, mostrando-lhe o modus operandis deste processo de sensibilizaçăo/formaçâo dos alunos, pera que este passe a ser uma prática implementada habitualmente pela própria escola. ${ }^{[25}$

A segunda estratégia tinha como alvo preferencial os pais (contexto familiar) com o objectivo de lhes dar informação complementar para que a educação que dão aos seus filhos, no âmbito da saúde oral, seja a mais correcta e eficiente possivel. ${ }^{\text {DSI }}$

As estratégias supra referidas corroboram com o que é preconizado pelo PNPSO, no âmbito da promoção da saúde oral no contexto familiar e escolar.

A promoção de saúde oral foi feita atraves de duas sessōes de formação, para as quais foi criada uma personagem, que foi interpretada pela formadora, com o objectivo de passar uma mensagem importante, de forma acessivel e atractiva. Nas sessões estiveram presentes os docentes das turmas e a enfermeira da escola conseguindo, assim, envolver nestas actividades parte da comunidade escolar. Para a realização destas sessões, envolvendo cerca de 75 crianças, foram utilizados diversos recursos didácticós $\mathrm{c}$ diversas metodologias de intervenção ${ }^{12}, 3,4,7, \eta$. A $1^{2}$ Sessĩo de formação: Relação entre higiene oral, saúde oral e alimentação saudável foi realizada com o objectivo geral de mostrar os beneficios de uma eficaz higiene oral. Traçaram-se quatro objectivos especificos (definir saúde oral, definir higiene oral, definir alimentaçã̃o "oralmente saudável" e relacionar os três conceitos) e para a sue consecução dividiu-se esta sessão em quatro partes. A primeira parte, introduçăo, destinada a criar um ambiente confortável - tendo-se constatado que muitas crianças tinham algum receio em relação ao que se ia fazer - $e$ a se definir alguns conceitos básicos sobre saúde oral. A segunda fase, de desenvolvimento, para sensibilizar as crianças para a importância de uma alimentaçåo saudável e de uma boa higiene oral para obter uma saúde oral eficaz, e a conclusĩo (terceira parte), onde através de uma canção, foram sintetizados os aspectos mais relevantes da sessão. A quarta parte, consistiu numa actividade de avaliação, onde se constatou que os objectivos desta sessão foram plenamente atingidos.

A $2^{a}$ Sessão de formação: Técnica de lavagem dos dentes e utilização do fio dentário, teve o objectivo geral de promover as técnicas de higiene oral nas crianças, tendo 
promote oral hygiene techniques in children and, specifically, to define the washing technique, summarizing the previous and current concepts. After a quick review on basic concepts from the last session, we moved on to the actual training (development). Conclusions were drawn by a game.

Finally, we've created a brochure with basic information regarding oral health in children between the ages of 4 and 5 , with language and messages apparently addressing children but mainly directly to move/train/inform their parents. This strategy was developed with the objective of not blaming the parents, because they intrinsically wish the best for their children, although sometimes their intervention and attitudes may result in the opposite direction (DGS-National Sehool Health Program) ${ }^{\text {If }}$.

\section{Conclusion}

The present study allowed us to demonstrate that several gaps and/or errors regarding oral hygiene existed in the studied population, and that these could not be overcome by moving, training and information campaigns exclusively directed to children, meaning that all the scholar community and parents should be involved.

Thus the predefined objectives were generally achieved with success since we managed to touch and train the scholar community and all its intervenient, parents included, to a better more effective oral hygiene, and healthier food for better oral health.

Planning and performing this type of course for such a special, also demanding, population as the scholar community, was the biggest difficulty we've faced. Also we were always concerned with the project's continuity which brought us a new responsability to our main educational task toward those. Another major difficulty consisted in the reduced number of national references available.

Finally it should be stressed that this kind of work cannot end with the project terminus. It should rather be regarded as an open, continued process in order to allow permanent improvement. The keynote of this intervention consisted in offering, to the school community, a set of instruments that may be developed, improved and adapted to different circumstances, thus allowing the school to become self-sufficient and an active promoter of its own intervention project. como objectivos espectficos: definir a técnica de lavagem dos dentes e sintetizar os conceitos dados durante esta sessão $\mathrm{e} \mathrm{a}$ anterior. Após relembrar o que havia sido dado na primeira sessão, passou-se à formação propriamente dita (desenvolvimento). A conclusão foi feita através de um jogo com o que se concretizaram as duas últimas fases da sessão (sintese e avaliação)

Finalmente, foi produzido um folheto com informaçōes básicas acerca da saúde oral nas crianças de 4 e 5 anos de idade, com uma linguagem e mensagem aparentemente dirigides is crianças, mas com o principal intuito de sensibilizar/formar/informar os pais. Esta estratégia foi desenvolvida com o objectivo de não culpabilizar os pais, porque estes, intrinsecamente, desejam sempre o melhor para os seus filhos, embora por vezes, algumas atitudes e intervençōes possam resultar em sentido contrário (DGSPrograma Nacional de Saúde Escolar) ${ }^{\text {t? }}$.

\section{Conclusä̃o}

A realizaçũo deste estudo permitiu demonstrar que havia, efectivamente, lacunas nos hábitos e conhecimentos dos alunos no que diz respeito ả higiene oral, e que essas não podiam ser resolvidas com acções de formação dirigidas exclusivamente d̀s crianças, levando a envolver, na sua dinâmica, toda a comunidade escolar e os pais. Desta forma, a generalidade dos objectivos, traçados ao longo deste Projecto, foram na sua maioria alcançados com sucesso, na medida em que se sensibilizou/formou a comunidade escolar (com todos os seus intervenientes) e os pais, para a necessidade de uma eficaz higiene oral e de uma alimentação "oralmente saudável" na obtenção de saúde oral.

As maiores dificuldades sentides ne concretização deste projecto foram o planear e realizar acçōes de formaçũo para um público-alvo tão especial e exigente como é a comunidade escolar. Ainda, o facto de ter existido sempre a preocupação de promover a continuidade destas acções, uma vez terminado o projecto, trouxe uma responsabilidade acrescida, à já tão grande responsabilidade que era formar, especificamente, aquelas crianças naquele momento concreto. Tornou-se também uma dificuldade, o facto de haver pouca bibliografia disponivel sobre esta temática a nível nacional.

Salienta-se, finalmente, a evidência de que este não pode ser um trabalho concluído com fim deste projecto, devendo ser visto como um processo aberto e continuado de forma a ser permanentemente melhorado. A grande mais valia desta intervençäo foi oferecer à comunidade escolar instrumentos que podem ser desenvolvidos, melhorados e adaptados dis diferentes circunstências, pretendendo, desta forma, que a escola se torne autosuficiente e promotora do seu próprio projecto de intervenção. 


\section{Appendix 1 - Form \\ Apendlce 1 - Formulário \\ FORM FOR ORAL HYGIENE HABITS IN CHILDREN \\ FORMULÁRIO SOBRE HÁBTTOS DE HIGIENE ORAL NAS CRIANÇAS}

1.Age / Idade:

2.Gender / Género

u-Male / Masculino

b.Female / Feminino

3.How many times a day you wash your teeth?

Quantes vezes por dia lavas os dentes?

4.One of these times is before going to sleep?

Uran dessas veres $\hat{k}$ antes de ir dormir?

n.Always / Sempre

b.Never / Nunca

c.Sometimes / As vezes

5. When you wash your teeth, do you wash the top of your tongue?

Quarodo lavis os dentes, lavas a parte de cima da tua lingua?

a.Always / Sempre

b.Never / Nunca

c.Sometimes /As vezes

6.Do You know what is dental floss?

Sabes o que c o fio dentario?

a. Yes / Sim

b.No/Nĩo

6.2If you know what it is, do you use dental floss?

Se sabes o que E, utilizas fio deatírio?

a.Always/Sempre

b.Never/Nubca

c.Sometimes / As vezes

7. Your toothbnush is used only by you?

A tua csoova de dentes é só utilizada por ti?

a. Yes / Sim

b.No/ Näp

8,Did someone explained to you how you should brush your tecth?

In te ensinaram como deves lavar os dentes?

a. Yes / Sim

b.No/NEa

8.2.If 50 , who did it ?

Se te ensinaram, quem foi?

9. When it cocnes to wash your teeth at home

Quando chega o moanento de lavar os deates em casa

a. Is there someane at your side to help

Há alguérn ao teu lndo a ajudar

b.Is there someone at your gide to see how to wash the teeth

Há alguém ao teu lado a ver como lavas os dentes

c.Is there someone at your side to help it and see how you wash the teeth

Ha alguém ao teu lado a ajudar a e ver como lavas os dentes

d.There's no abe beside you

Nĩo há ninguém no teu lado

10.Did someone explnined to you that to shalt good teeth you must brust them?

Alguém te explicau que para teres uns deates bons deves lavar os dentes?

a. No / Näo

b. Yes/ Sim 


\section{Appendix 1 - Form \\ Apendice 1 - Formulárlo}

\subsection{Se te explicaram, quem foi? \\ If So, who did it?}

11.Do you wash your teeth at school?

Na escola, lavas os dentes?

a. Yes / Sim

b.No / Nïo

e.Sometimes / As vezes

\subsection{If you wnsh them at school}

Se lavas na escola:

a.Is there someone at your side to help

Há alguém no teu lado a ajudar

b.Is there someone at your side to see bow to wash the teeth

Ha alguém ao teu liedo a ver como lavas os dentes

c.Is there someone at your side to belp it and see how you wash the teeth

Hu alguem ab teu lado a ajudar a e ver como lavas os dentes

d. There's no one beside you

Noto ha ninguem ao teu lado

12. How many times a day you eat candies?

Quastas vezes por dis comes doces?

13. When do you eat candies ?

Quando comes doces?

a.During Menls

Durante as comidas

b.Between Meals

Fora das comidas

c. Whatever

Tanto faz

14. Where dip you eat candies?

Onde comes os doces?

15.After you ent candies, do you wash your teeth?

Depois de comeres doces, lavas os dentes?

n.Always / Sernpre

b.Never/Nuncn

c.Sometimes / As veres

16.Did someone explained to you that enting too many candies is bad for teeth?

Alguem te explicou que comer muitos doces faz mal aos dentes?

a.No $/ \mathrm{N} J 0$

b.Yes / Sim

16.2.If so, who did it?

Se jós te explicaram, çuem foi'? 
Appendix 2 - Answers

Apêndice 2 - Respostas

\begin{tabular}{|c|c|c|}
\hline $\begin{array}{c}\text { Answer } \\
\text { Rerpostn 1 }\end{array}$ & $\begin{array}{c}\text { Frequency } \\
\text { Frequencin (o) }\end{array}$ & $\begin{array}{c}\text { Relative Frequency } \\
\text { Frequetncia Relattva (\%) }\end{array}$ \\
\hline 4 & 4 & 16 \\
\hline 5 & 21 & 84 \\
\hline Total & 25 & 100 \\
\hline
\end{tabular}

\begin{tabular}{|c|c|c|}
\hline $\begin{array}{c}\text { Answer } \\
\text { Resposta2 }\end{array}$ & $\begin{array}{l}\text { Prequency } \\
\text { Frequhalia(n) }\end{array}$ & 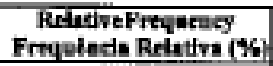 \\
\hline Male /Mascaliso & II & 44 \\
\hline Femele/Feminino & 14 & 56 \\
\hline Total & 25 & 100 \\
\hline
\end{tabular}

\begin{tabular}{|c|c|c|}
\hline $\begin{array}{c}\text { Anumer } \\
\text { Regponta } 3 \\
\end{array}$ & $\begin{array}{l}\text { Frequency } \\
\text { Fresuleclá(0) }\end{array}$ & 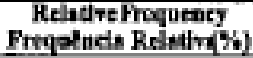 \\
\hline $\begin{array}{l}\text { Lentben } 2 \text { times / day } \\
\text { Meme de } 2 \text { verses / dia }\end{array}$ & 8 & 32 \\
\hline $\begin{array}{l}2 \text { of more times / thy } \\
2 \text { on muis veres / diat }\end{array}$ & I7 & 68 \\
\hline Total & 25 & 100 \\
\hline
\end{tabular}

\begin{tabular}{|c|c|c|}
\hline $\begin{array}{c}\text { Aaswer } \\
\text { Responta } 4\end{array}$ & $\begin{array}{c}\text { Froqeency } \\
\text { Prequencts(a) }\end{array}$ & $\begin{array}{l}\text { Relative Frequenc, } \\
\text { Frequata Retatlve\%) }\end{array}$ \\
\hline Always/Sempic & 16 & 64 \\
\hline Sontrimedtern mexprt & 9 & 36 \\
\hline Tetal & 25 & 100 \\
\hline
\end{tabular}

\begin{tabular}{|c|c|c|}
\hline $\begin{array}{c}\text { Answer } \\
\text { Regpostas }\end{array}$ & 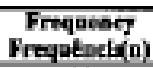 & $\begin{array}{l}\text { Rentive Frequeocy } \\
\text { Frequlocle Relstivi } \% \text { ) }\end{array}$ \\
\hline Alwhys'Semper & 14 & 56 \\
\hline Sonetaneavem Mnspe & 11 & 44 \\
\hline Total & 25 & 100 \\
\hline
\end{tabular}

\begin{tabular}{|c|c|c|}
\hline $\begin{array}{c}\text { Answer } \\
\text { Reeposta }\end{array}$ & $\begin{array}{c}\text { Froqutney } \\
\text { Frequemedr(a) }\end{array}$ & $\begin{array}{c}\text { RelativelFrequency } \\
\text { Frequetacla Relativi\%) }\end{array}$ \\
\hline Yes/Sin & 8 & 32 \\
\hline No/NLo & 17 & 68 \\
\hline Total & 25 & 100 \\
\hline
\end{tabular}

\begin{tabular}{|c|c|c|}
\hline Aemer & $\begin{array}{l}\text { Frequency } \\
\text { Frequetenciva) }\end{array}$ & $\begin{array}{c}\text { Beintive Frequency } \\
\text { Froquencia Pelative'\%) }\end{array}$ \\
\hline Always Seutpre & 2 & 25 \\
\hline Sontetimeakem sengre & 6 & 75 \\
\hline Total & 8 & 100 \\
\hline
\end{tabular}

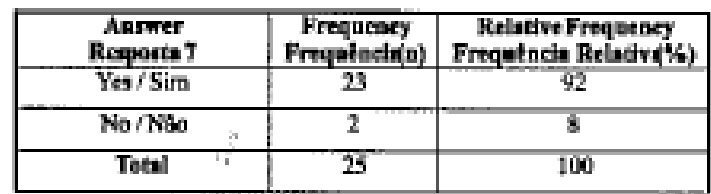

\begin{tabular}{|c|c|c|}
\hline $\begin{array}{l}\text { Answer } \\
\text { Rerportas }\end{array}$ & $\begin{array}{l}\text { Frequency } \\
\text { Frequlacis(n) }\end{array}$ & 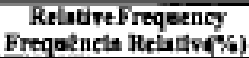 \\
\hline Yes/Sin & 15 & 60 \\
\hline No/NIo & 10 & 40 \\
\hline Total & 25 & 100 \\
\hline
\end{tabular}

\begin{tabular}{|c|c|c|}
\hline $\begin{array}{c}\text { Answer } \\
\text { Retpentas.2 }\end{array}$ & $\begin{array}{c}\text { Frequency } \\
\text { Frequetsidin) }\end{array}$ & 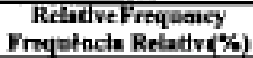 \\
\hline Partits/Pais & 13 & 86,6 \\
\hline IV & 1 & 6.6 \\
\hline $\begin{array}{l}\text { Cas't Reswentiex } \\
\text { Nin es kenten }\end{array}$ & 1 & 6,6 \\
\hline Total & I5 & 100 \\
\hline
\end{tabular}

\begin{tabular}{|c|c|c|}
\hline $\begin{array}{c}\text { Anrmer } \\
\text { Resposta9 }\end{array}$ & $\begin{array}{l}\text { Frequency } \\
\text { Frequencin(a) }\end{array}$ & $\begin{array}{l}\text { Hetadive Freqoncy } \\
\text { Frequedoch Relintiva } \% \text { ) }\end{array}$ \\
\hline Yes/Sim & 20 & B0 \\
\hline $\mathrm{Ne} / \mathrm{Ni}$ e & 5 & 20 \\
\hline Total & 25 & 160 \\
\hline
\end{tabular}

\begin{tabular}{|c|c|c|}
\hline $\begin{array}{c}\text { Anawer } \\
\text { Recposta } 10\end{array}$ & $\begin{array}{c}\text { Frequency } \\
\text { Frequetuds(b) }\end{array}$ & $\begin{array}{c}\text { Relative Frequency } \\
\text { Frequlacis Relotivg } \% \text { ) }\end{array}$ \\
\hline $\mathrm{Yes} / \mathrm{Sin}$ & 18 & 72 \\
\hline No/NSo & 7 & 28 \\
\hline Total & 25 & 100 \\
\hline
\end{tabular}

\begin{tabular}{|c|c|c|}
\hline $\begin{array}{c}\text { Aeswer } \\
\text { Respesta 10.2 }\end{array}$ & $\begin{array}{c}\text { Frequequcy } \\
\text { Frequêneis(n) }\end{array}$ & $\begin{array}{c}\text { Relnttvofrequency } \\
\text { Frequenein Relntivi } \% \text { ) }\end{array}$ \\
\hline Parents / Pais & 10 & 55,6 \\
\hline Dentist /Dentiskn & I & 5.6 \\
\hline TV & 2 & 11,1 \\
\hline $\begin{array}{l}\text { Can't Remember } \\
\text { NHo se lentres }\end{array}$ & 5 & 27,7 \\
\hline Total & I8 & 100 \\
\hline
\end{tabular}

\begin{tabular}{|c|c|c|}
\hline $\begin{array}{c}\text { Aawer } \\
\text { Respesta11 }\end{array}$ & $\begin{array}{l}\text { Frequency } \\
\text { Frequendi(n) }\end{array}$ & $\begin{array}{c}\text { RelativeFrequency } \\
\text { Frtequlatin Relativd } \% \text { ) }\end{array}$ \\
\hline Yes/Sim & I & 4 \\
\hline No / Näo & 24 & 96 \\
\hline Total & 25 & 100 \\
\hline
\end{tabular}

\begin{tabular}{|c|c|c|}
\hline $\begin{array}{c}\text { Answer } \\
\text { Respostall.2 }\end{array}$ & $\begin{array}{c}\text { Frequency } \\
\text { Frequêtid(n) }\end{array}$ & $\begin{array}{l}\text { Pelative Frequeucy } \\
\text { Frequâcla Beintive( } \% \text { ) }\end{array}$ \\
\hline Yes/Sim & 0 & 0 \\
\hline $\mathrm{No} / \mathrm{NB}$ & 1 & 100 \\
\hline Total & 1 & 100 \\
\hline
\end{tabular}

\begin{tabular}{|c|c|c|}
\hline $\begin{array}{c}\text { Aaswer } \\
\text { Resposta 12 } \\
\end{array}$ & $\begin{array}{c}\text { Frequency } \\
\text { Frequededa(n) }\end{array}$ & $\begin{array}{c}\text { Relative Frequeney } \\
\text { Frequeneia Relattra }\end{array}$ \\
\hline $\begin{array}{c}\text { None } \\
\text { Nenhumn, nin gosta }\end{array}$ & 1 & 4 \\
\hline $\begin{array}{l}\text { Up to twic / dopg } \\
\text { Até duas vezes / dia }\end{array}$ & 21 & $B 4$ \\
\hline $\begin{array}{l}\text { Mare thun } 2 \text { times / day } \\
\text { Mais de } 2 \text { veres / dis }\end{array}$ & 3 & 12 \\
\hline Total & 25 & 100 \\
\hline
\end{tabular}

\begin{tabular}{|c|c|c|}
\hline $\begin{array}{c}\text { Answer } \\
\text { Resposta } 13\end{array}$ & $\begin{array}{c}\text { Frequeacy } \\
\text { Frequerrie(n) }\end{array}$ & $\begin{array}{l}\text { Relative Frequeney } \\
\text { FrequEnela Relativg\%) }\end{array}$ \\
\hline $\begin{array}{c}\text { During meal } \\
\text { Duranle a refeicla }\end{array}$ & 4 & 16,7 \\
\hline $\begin{array}{l}\text { between med } \\
\text { Fon da refeiphio }\end{array}$ & 20 & 83,3 \\
\hline Total & 24 & 100 \\
\hline
\end{tabular}

\begin{tabular}{|c|c|c|}
\hline $\begin{array}{c}\text { Answer } \\
\text { Respesta14 }\end{array}$ & $\begin{array}{c}\text { Frequency } \\
\text { Frequlacis(a) }\end{array}$ & $\begin{array}{c}\text { Relative Frequency } \\
\text { Frequtacin Relethn }(\%)\end{array}$ \\
\hline Everis / Festas & 10 & \\
\hline Home / Cess & 16 & \\
\hline School/Ercoli & 5 & \\
\hline Restaunan(c) & I & \\
\hline Gardah / Jardian & 1 & \\
\hline Total & & \\
\hline
\end{tabular}

\begin{tabular}{|c|c|c|}
\hline $\begin{array}{c}\text { Anmwer } \\
\text { Raperta15 } \\
\end{array}$ & $\begin{array}{l}\text { Frequency } \\
\text { Frequeladi(n) }\end{array}$ & $\begin{array}{c}\text { Relative Frequency } \\
\text { Frequefucla Relativs } \% \text { ) }\end{array}$ \\
\hline Always / Sempre & 8 & 33,3 \\
\hline $\begin{array}{l}\text { Semetimes } \\
\text { Nern sempre }\end{array}$ & 16 & 66,6 \\
\hline Total & 24 & 100 \\
\hline
\end{tabular}

\begin{tabular}{|c|c|c|}
\hline $\begin{array}{c}\text { Anmwer } \\
\text { Reaposta16 }\end{array}$ & $\begin{array}{l}\text { Frequescy } \\
\text { ErequEndala) }\end{array}$ & 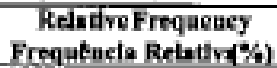 \\
\hline $\mathrm{Y} \in \mathrm{s} / \mathrm{Sim}$ & 18 & 72 \\
\hline No $/$ Nas & 7 & 28 \\
\hline Total & 25 & 100 \\
\hline
\end{tabular}




\section{References / Referênetas}

[1]. Betslht LM. Promechio fin Safide Otral nas Crimcas: de tearia ex pritica. Sevir 2001; 49 (4): 15g-64.

[2]. Direcyãn Geral de Saíde. Prognama Nacienal de Promoctode Saúde Onal Lisbea:DGS; 2005.

[3]. Hockenberry MJ. Wong Fundamentos de Enfermegen Pedistrice 7 th ed. Rjo de Janeiro: Elservier; 2005.

[4]. Direçlo Gerul de Sulade. Plano Nacionel de Satade 2004-20t0: mais saúde para todos. Lísbea: DGS; 2004.

[5].Dirteglo Getral de Saúde. Prograns Nacional de Saćde Escolat. Lisboa: DGS; 2006.
[6]. Redmea BK. A Pratica de Edueacho pard a Saude. 9 thed. Loures: Lusoeitneis. 2003.

[7. Cnssandra KA, Oppermath CS. Enferenagem Pedtidtrica Contemporânes. Loures: Lusicieacia: 2001 .

[8]-Laecastet J, Stanhope M. Enferanagem Corrunitírix Promocăo da saide de grupes, fumillia eindividoos. 4 th ed. Lourea: Luocilencia; 1999 .

[9].Hiteman-Fanson SM. Enfermapem de Cuidados bo Saùde a Fanilia: Teorin, prácticn e Irvestigaçlo. 2 nd ed. Loures: Lusucielncir; 2009

[10]. Fortin ME, O Processe de Investignela. 3 rd ed. Loures: Luscikncia; 1996.
[11]. Haber J, Lobicedo-Wood G. Pesquish an Enfermagem: Métodos, avaliaçðo etitica e etiliracto, 4 ta o4. Rio do Janeire: Guknaburs. Koogas 2001

[12].Polit DF, Beck CT, Hungler BP. Funderneadns do Pespuiss em Enfitrnagem Mtodos, avaliacto e utilizapino. 5 thed. Sto Paulo:Artmed; 2004.

[13]. Qvivy R, Campenhoudt L Marual de lavestigaçalo em cienciss socinis. 3 nd ed. Lisbes: Gralive 2000. 